\title{
Diminished Realityを用いた構造物撤去新設時の 景観検討AR実現に関する研究
}

\author{
矢吹 信喜 1 - 種村 貴士 2 - 福田 知弘 3 - 道川 隆士 4 \\ 1フェロー会員 大阪大学教授 大学院工学研究科 環境・エネルギー工学専攻 \\ ( ₹565-0871 大阪府吹田市山田丘2-1) \\ E-mail: yabuki@see.eng.osaka-u.ac.jp \\ 2学生会員 大阪大学大学院工学研究科 環境・エネルギー工学専攻 博士前期課程 \\ 3 正会員 大阪大学准教授 大学院工学研究科 環境・エネルギー工学専攻 \\ 4非会員 大阪大学特任助教 環境イノベーションデザインセンター
}

\begin{abstract}
近年，土木建築分野での景観検討において，AR（Augmented Reality）が注目されている.しかし，現 在のAR技術では，既設構造物を解体，撤去し，そこに新たに構造物を建設することを想定して景観検討 を行う場合, 解体, 撤去予定の既設構造物と, 重畳寸る新設構造物の3次元モデルが交わって表示され, 本来見えるべきでない既設構造物の一部が見えてしまい，適切な景観検討ができないという問題がある. 一方で, 背景画像を除去対象物領域に重畳することで障害物を取り除く技術であるDR（Diminished Reality）が着目されている. 本研究では, 3次元点群データを用いて, 建物の解体, 撤去時の景観検討で の利用を想定した, 屋外大規模構造物を対象としたDR手法を開発し, 開発したシステムの検証実験を行 った.
\end{abstract}

Key Words : Augmented Reality, Diminished Reality, point cloud data, Demolition, Urban Planning

\section{1. はじめに}

\section{（1）土木建築分野における景観検討手法の現状と課題}

近年，環境デザイン，土木建築分野での景観検討にお いて，既設構造物を解体，撤去し，そこに新たに構造物 を建設することを想定して景観検討を行う様々な手法が 提案されている1). コンピュータの中で仮想的に作られ た環境である仮想世界を，現害空間のように体感するこ とができる技術としてVR（Virtual Reality）がある.VRで は簡単な操作で視点の移動などを行うことが可能であり 3DCGによる景観検討のような，専門的な知識を必要と しないため，住民参加型の景観シミュレーションツール 2)などにも応用されている．また，ビルや橋梁などの大 規模構造物を新規に建設する際などにも，VRを用いた 景観シミュレーションによる景観検討が行われるように なりつつある。しかし，VRには，仮想世界の作成に大 きな時間的，費用的コストが必要となるという課題があ る. カメラ動画像に3次元モデルを重畳することで周辺 環境の3次元モデルの作成を必要とせず，時間的，費用 的コストを削減できる技術としてAR（Augmented Reality）がある3)．ARを用いた景観検討手法は多く提案
されている.しかし，既設構造物を解体，撤去し，そこ に新たに構造物を建設することを想定して景観検討を行 う場合，解体，撤去する予定の既設構造物と，重畳寸る 新設構造物の3次元モデルが交わって表示され，本来見 えるべきでない既設構造物の一部が見えてしまい，適切 な景観検討ができないという問題がある.

\section{(2) DR技術}

この問題を解決する技術として，背景画像を除去対象 物領域に重悋合わせることにより，障害物を取り除く技 術である DR (Diminished Reality) が着目されている ${ }^{4}$.

$\mathrm{DR}$ 技術を加えた $\mathrm{AR}$ による景観シミュレーション手法 であれば，先ほど述べた既設構造物と 3D モデルの交わ り問題は解決できると考えられる. DR の手法には, 静 止画像中の除去対象物に，背景画像を重畳する方法 5) あらかじめ撮影された動画像に対して，背景画像の重畳 を行うプリレンダリング方式による方法 9，またリアル タイム動画像に対応した，リアルタイムレンダリング方 式の方法 》など，様々な手法が存在するが，屋外の大規 模構造物の解体，撤去時の景観検討としての利用では, 現地において任意の視点からの検討を求められることが 
多いため, リアルタイム動画像に対応したリアルタイム レンダリング方式の DR 手法が有効であると考えられる リアルタイムレンダリング方式の DR 手法は, 背景画像 として使用寸る仮想世界の作成方法に関して, リアルタ イムに仮想世界を作成しながら，DR シミュレーション を行う手法と，DR シミュレーションを行う前に仮想世 界を作成しておく手法の 2 種類に大別することができる

リアルタイムに背景画像として使用する仮想世界を作 成する DR 手法としては，マーカと複数のカメラを使用 して, 一つのカメラが取得した画像に対して, 他の複数 のカメラが取得した背景領域の画像を重畳することによ って DRを実現する方法や, 超音波カメラやステレオカ メラの内視鏡などの特殊なイメージセンサを用いて背景 画像を取得する方法 ${ }^{8}$ がある. しかし，マーカと複数の カメラを使用する方法では各カメラ画像中でマーカを大 きくとらえる必要があるため, 除去対象物が近距離に存 在する場合でないと, 適切な DRができない. また, 超 音波カメラやステレオカメラの内視鏡など, 特殊なイメ ージセンサを用いる手法においても，主に医療分野で用 いられるものが多いため, 除去対象物が近距離に存在す る場合でないと，適切な DRができず，屋外での大規模 構造物を対象とした景観検討に利用するには実用的でな いと考えられる.

DR シミュレーションを行う対象地周辺の仮想世界を あらかじめ作成しておく DR 手法としては, DR シミュ レーションを行う対象地周辺の, 除去対象物のない状態 の仮想世界を VR モデリング等であらかじめ作成してお き, DR シミュレーション時に除去対象物に重畳する方

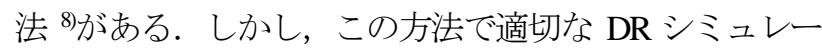
ションを行うためには, 周辺環境を詳細にモデリングす る必要があるため, 時間的, 費用的コストが大きくなる といった問題がある.

屋外での大規模構造物の解体，撤去を想定した景観検 討でDR技術を用いる場合, 現状では後者の, DRシミュ レーションを行う前に仮想世界を作成しておく手法を用 いる方が適切であると考えられる. しかし仮想世界を詳 細にモデリングすることによる時間的，費用的コストを 小さくする実用的な解決方法は見当たらず，屋外での大 規模構造物を対象とするような効率的，実用的な $\mathrm{DR}$ 手 法はまだないのが現状である.

一方で，3次元レーザースキャナによる3次元点群デー タの計測技術も近年注目されている. 3次元レーザース キャナは, 高精度で物体の3次元の幾何学的構造を計測 することが可能な装置である. また，車載式の3次元レ ーザースキャナを用いて, 走行しながら3次元点群デー タを計測するMMS（Mobile Mapping System）の出現によ って, 都市や国スケールでの広域的な計測が可能となっ た. 多くのMMSでは, 物体の3次元幾何学的構造だけで
なく，同時にその色も計測することができる．MMSに よる計測では，固定式の3次元レーザースキャナに比心゙ て精度が劣化してしまう問題点があるが，高精度GPS移 動計測装置三菱モービルマッピングシステム9などのよ うに, これらの問題は日々改善されている. 3次元レー ザースキャナやMMSは非常に高価な装置であるため, 景観検討や景観シミュレーションのような目的での購入 を想定することはあまり現実的ではない.しかしながら， 近年の急速な情報化技術の進歩および各測量会社が3次 元レーザースキャナやMMSを所有し，様々な土木構造 物の3次元点群データを計測している現状を考えると， 今後, あらゆる場所の3次元点群データが自由に入手可 能となることが期待される.

本研究では3次元点群データ（Point Cloud）を用いて, 建物の解体，撤去時の景観検討での利用を想定した，屋 外大規模構造物を対象としたDR手法を開発することを 目的とし，開発したシステムの検証実験を行うこととし た. 本研究では, 3次元レーザースキャナにより, 大都 市を中心に大半の構造物が3次元点群データとして計測 され，容易に入手可能な将来の状況を想定している.

\section{2. 既往の研究}

\section{(1) リアルタイムレンダリング方式のDR技術}

第1章で述べたように，リアルタイムレンダリング方 式の DR 手法は，リアルタイムに仮想世界を作成しなが ら DR シミュレーションを行う手法と, DR シミュレー ションを行う前に仮想世界を作成しておく手法の 2 種類 に大別することができる. 本節ではそれら 2 種類の手法 の既往の研究に関して概説する.

a) リアルタイムに仮想世界を作成しながら, DR シミ ユレーションを行う手法

榎本ら》は, 複数の視点カメラを用いて DR を行う際

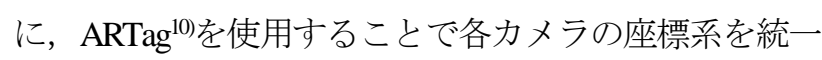
することによって各画像の透視投影変換, 各視点の移動 を可能にし, 一つのカメラの画像に対して, 別のカメラ が取得した背景画像を，透視投影変換を行って重畳する ことにより DRを実現している．しかし，幾何学的整合 性をもった DR を実現するためには, 各カメラ画像中で マーカを大きくとらえる必要があるため, 屋外での大規 模構造物を除去対象物として使用する際には不具合が生 じる可能性が高いと考えられる.

b) DR シミュレーションを行う前に仮想世界を作成し ておく手法

Cosco ら けは, 屋内において, 移動させることが可能 な物体を除去対象物とし, 除去対象物がない状態での背 景領域の映像を撮影し，幾何形状をあらかじめパッチに 
分割しておき, DR シミュレーションの際に，除去対象 物に事前に撮影した背景映像を利用した Image Based Rendering（IBR）を用いて，DRを実現している．除去対 象物を自由に移動させることができる場合，この手法は 有用であるが，屋外の大規模構造物など，自由に移動さ せることが不可能な物体を除去対象物とする場合，DR を実現するのは難しいと考えられる.

\section{(2) 位置合わせ手法}

本研究で提案する DR 手法では, 背景画像として 3 次 元点群データを用いるが，背景画像を重畳して表示する 際に周りの現実世界との幾何学的整合性をとる必要があ り，そのために，現実世界と 3 次元点群データの存在す る仮想世界との位置合わせを行う必要がある。これは, 現実世界に仮想物体を重畳寸る ARにおいても同様の課 題である. AR の代表的な位置合わせ手法としては以下 のようなものがある.

\section{a) 人為的マ一カを用いる手法}

人為的マーカを用いる手法は, あらかじめコンピュー タにデザインが登録されたマーカを使用することで安定 かつ高速にカメラの位置・姿勢を推定することができる また，カメラ以外に特殊なセンサーを必要としないため, 低コストで持ち運びに優れている．しかし，カメラがマ 一カを正しく認識できる距離にマーカを設置する必要が あるため，屋外での大規模構造物を対象とした景観検討 時などは，誤差が生じ易いといった問題がある.

\section{b) GPS (Global Positioning System) とジャイロスコー プを用いる手法}

GPS とジャイロスコープを用いる手法は, GPS により 位置情報（緯度，経度，標高）を，ジャイロスコープに より角度情報（yaw, pitch, roll）を取得するため，視点や 環境の変化に対応し易く, カメラの位置・向き等が容易 に計測でき, 高精度である。しかし，精度が機器に依存 し，高精度を得るためには，高価で重く特殊なハードウ エアが必要であり, また, 移動可能範囲がセンサーの有 効範囲内に限られるという問題がある.

\section{c) 自然特徵点を抽出し, 既知の点と照合する手法}

自然特徵点を利用する方法は, 環境中に自然に存在す る物体の特徵点を抽出し，その三次元位置を推定するた め人為的指標を用意寸る必要がない。しかし，抽出した 特徵点と構造物の既知の点の座標值を一致させることが 現状では難しく, 現状としては特徽点をあらかじめ設置 することや11あらかじめ撮影された映像に処理をするプ リレンダリング方式を用いて ${ }^{12)} \mathrm{AR}$ を実現することが必 要である. これは, 自然特徴点には位置合わせの基準と なる座標系が定義されていないためであり，そのままで は現実世界と仮想世界の相対的な位置関係を決定するこ とができないことが問題である.
上記の3つの手法の中でも，自然特徵点を抽出し，既 知の点と照合する手法は，人為的指標を使用しなくとも 位置合わせが可能になるため, 現在盛んに研究が行われ ている. 自然特徵点を抽出し, 既知の点と照合する手法 の応用研究として, Yabukiら ${ }^{13}$ の提案した, 3次元点群デ 一タと自然特徵点を対応させる位置合わせ手法がある.

この手法では, 現実世界の画像中の構造物の角などの特 徵点と, 3次元点群データ中の構造物の同じ箇所の位置 情報を持った点群データを対応付けることにより，現実 世界と仮想世界との位置合わせを行っている。 この手法 は，あらかじめ3次元レーザースキャナにより計測され た大量の3次元点群データがあれば，自然特徴点を用い る位置合わせ手法において困難だとされている現実世界 と仮想世界の相対的な位置関係がわかり，特殊な機材や 人為的指標を使用しなくとも高精度の位置合わせを行う ことを可能にしている. 本研究で提案する手法では, 3 次元点群データを用いて屋外大規模構造物を対象とした DRシミュレーションを行うことから，Yabukiら ${ }^{13}$ による 3次元点群データと自然特徴点を対応させる位置合わせ 手法を採用した.

\section{（3） 3次元レーザースキャナと3次元点群データの応用 研究}

3 次元レーザースキャナは対象物に対してレーザーを 照射し, その反射波加対象物の 3 次元座標を計測し, 3 次元点群データとして取得することができるシステム である. 本研究では, タイム・オブ・フライト方式の 固定式レーザースキャナおよび MMS によって取得した 3 次元点群データを使用した. タイム・オブ・フライト 方式では，レーザーの照射時刻から反射波の到達時刻ま での間に経過した時間によって対象物までの距離を計測 する．レーザーの照射角度を正確に定めることで，物体 の 3 次元座標を計測することができ, 最大三百メートル の測定可能範囲を持つ。また， MMS は，レーザースキ ヤナや GPS アンテナなどを車両に搭載し，道路を走行 しながら道路周辺の対象物の 3 次元座標を計測するシス

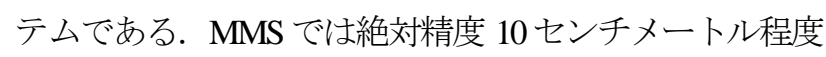
の精度で計測を行うことが可能である.

上記のように，3次元点群データは3次元位置情報計測 時の状況を高精度にデータとして保持することが可能で ある. 本研究では, 3次元点群デー夕を, 位置合わせや DRを実現するための仮想世界作成において利用してい る. ARにおける現実世界と仮想世界との位置合わせの 際に3次元点群データを用いた研究として, 高奥ら ${ }^{14}$ は, 3次元点群データの中から, あらかじめ設定した4点を用 いて行う位置合わせ手法を開発している. また，3次元 点群データから, 仮想世界を構成する3次元モデルを生 成する研究として, 鈴木ら ${ }^{1516}$ は, 3次元点群データから 
三角形メッシュを生成する手法を開発し，北川ら ${ }^{17}$ は， 都市・建築模型の幾何的特徴に着目し，3次元点群デー タから凸多角形および非凸多角形などの3次元形状を対 話的にモデリングするシステムを開発するなど，3次元 点群データの利用可能性は広がっているといえる.

\section{PCDRシステム}

\section{(1) PCDRシステムの概要}

本研究で開発したシステムはPoint Cloud Diminished Reality Simulation Systemであり，PCDRシステムと略称する. PCDRシステムの動作メカニズムの平面図を図-1に示す. PCDRシステムは，コンピュータに接続したカメラから 撮影した映像中の除去対象物の背後にある不可視領域を 3次元点群データによる仮想世界で除去対象物領域に合 成することにより，DRを実現する。背景画像として使 用する3次元点群データは，予めPCDRシステム内に保存 しておく必要がある。本研究では，3次元レーザースキ ヤナにより，大都市を中心に大半の構造物が3次元点群 データとして計測され，容易に入手可能な将来の状況を 想定している.

\section{(2) PCDRシステムのアルゴリズム}

PCDRシステムのDRシミュレーションのアルゴリズム を説明する.アルゴリズムフローを図-2に示す。

\section{a) 位置合わせ}

PCDRシステムは，起動後，カメラ位置のGPS座標を 入力し, カメラ画像中の特徴点と3次元点群データを用 いて位置合わせを行う。カメラ画像中の，同一平面上に ある建物の角などの特徵点と，3次元点群データ中の同 じ箇所を4点以上対応付けることで位置合わせを行う。
位置合わせ後，仮想世界表示プロセスと合成領域決定プ ロセスに分かれる．仮想世界表示プロセスでは，別ウィ ンドウで，位置合わせの行われた3次元点群データによ る仮想世界を表示しておく，合成領域決定プロセスでは， カメラ画像に合成する仮想世界の合成領域を決定する.

\section{b) 除去対象物の3次元モデルデータ表示}

合成領域決定プロセスでは，位置合わせ後，カメラ画 像中の除去対象物には, 除去対象物の緑色の3次元モデ ルが重畳される，これは，現実世界で除去対象物が位置 している場所の，平面直角座標系における座標を指定し ておき，仮想世界の同じ位置に除去対象物のVRMLモデ ルを平行移動させて表示しているためである。この3次 元モデルは，後の二值化処理の際，除去対象物領域を他 の領域と区別するのに使用するため，色情報を(R, G, B) $=(0,255,0)$ で作成しておく必要がある.

\section{c) カメラ画像の二値化処理}

次に, Cameraウィンドウの画像をキャプチャする.キ ヤプチャした画像をBitmap形式で保存し，この保存した 画像に対して二值化処理を行う。二值化処理では， $(\mathrm{R}$, $\mathrm{G}, \mathrm{B})=(0,255,0)$ の3次元モデルが重畳されたカメラ画像 を赤緑青の3チャネルに分離し，緑色の色要素のみを持 った，緑チャネルのグレースケール画像を取得する．取 得したグレースケール画像に対して，輝度值が255より 小さいピクセルを全て輝度值0（黒色）とし，輝度值が 255 (白色）であるピクセルには変更を加えない二值化 処理を加え，マスク画像を作成する，マスク画像におい て，緑色の除去対象物の3次元モデルが重畳された領域 は白色になり，他の領域は黒色になっている．以上が合 成領域決定プロセスである.

\section{d) クロマキ一処理}

Cameraウィンドウに表示された，現実世界の除去対象 物に，除去対象物の緑色VRMLモデルが重畳しているカ メラ画像と, PointCloudウィンドウに表示されている,

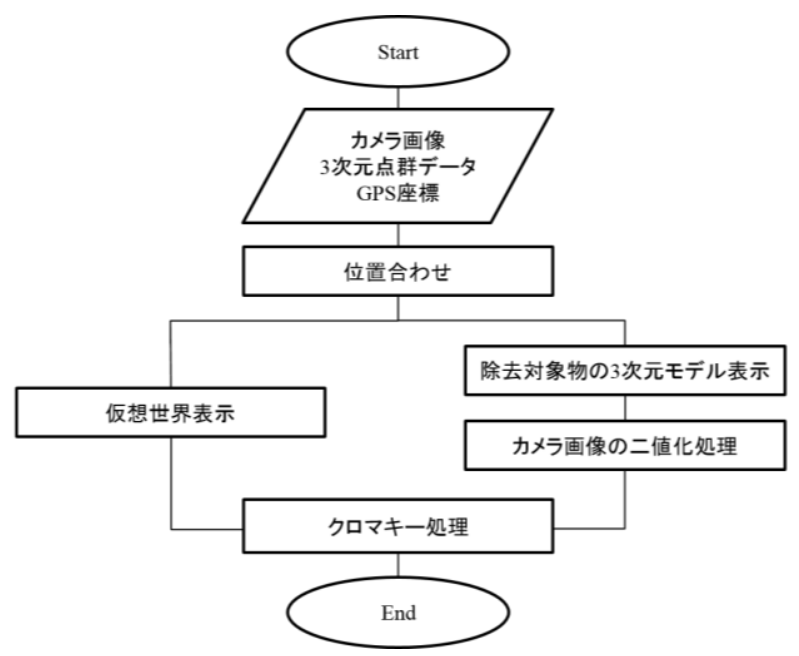

図-2ＰCDRシステムのアルゴリズムフロー
図-1ＰCDRシステム動作メカニズムの平面図

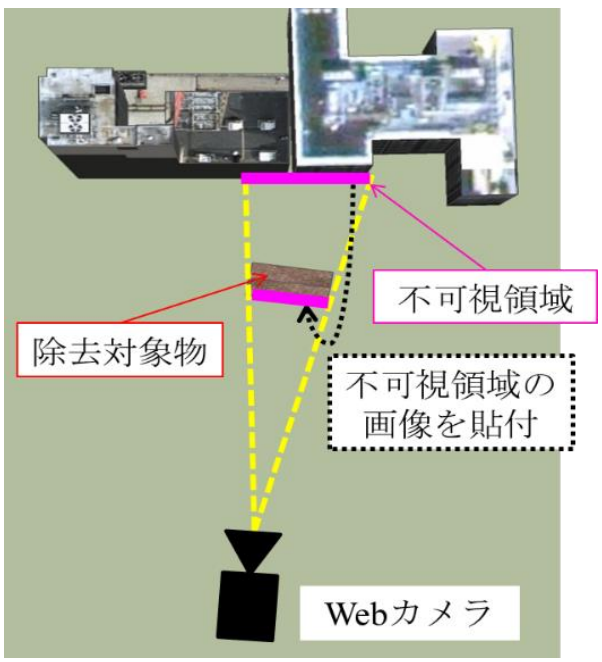


景観シミュレーション対象地周辺の3次元点群データか ら構成される仮想世界の画像，および二值化処理の際に 作成したマスク画像を用いてクロマキー合成を行う。

マスク画像の白色の領域のみを，位置合わせの行われた 背景画像として使用寸る3次元点群データから, カメラ 画像にコピーすることで, カメラから不可視領域を，3 次元点群データによる仮想世界で除去対象物領域に合成 し，DRが実現する．PCDRシステムは，位置合わせの際 に3次元点群データと対応付けられた特徵点をカメラ映 像に追随して, トラッキングを行うので, 動画像へも適 用可能である. しかし, 素早い視点の移動を行うと点群 データと特徴点の対応付けが失われてしまい, DRが続 行不可能となる。.また, 位置合わせの際に使用した画像 中の特徽点が視点の移動によって画像の外に出てしまっ た場合もDRが続行不可能となる．PCDRシステムは，仮 想世界として使用寸る3次元点群データの色調を調整す る機能も実装しているため, 現実世界と仮想世界との光 学的整合性をとることが可能である.

\section{(3) PCDRシステムの制約条件}

PCDRシステムの屋外検証実験を行う際，考慮しなけ ればならない制約条件を以下に列挙する.

\section{a) 除去対象物の背景の3次元点群データが取得されて いること}

除去対象物の背景の3次元点群データが十分に取得さ れていない場合，3次元点群データのみでは，現実世界 との幾何学的整合性のある仮想世界の作成が難しいため, 3次元モデリングで補う必要がある．そのため, 背景の3 次元点群データが十分に取得されているような位置関係 である，除去対象物とカメラの視点の位置を選定する必 要がある.

b) カメラの視点と除去対象物の間に障害物が存在しな

\section{いこと}

カメラが除去対象物をとらえる際に，除去対象物より 手前に樹木等の障害物が存在する場合, 背景画像を重冨 することによって，手前に存在する樹木が部分的に見え なくなってしまい，幾何学的整合性が失われる可能性が ある. 適切な景観検討を行うためには, カメラの視点と 除去対象物の間に障害物の存在しない場所を選定する必 要がある.

\section{c) 3次元点群データを用いての位置合わせを行うこと が可能であること}

PCDRシステムは3次元点群データと自然特徴点とを 対応付けて位置合わせを行うため，カメラは，位置合わ せの対象とする構造物をとらえ続ける必要があり, なお かつその構造物の3次元点群データが取得されている必 要がある.

\section{PCDRシステムの検証実験}

3章で述べた制約条件をふまえ，PCDRシステムの検証 実験を行った.

\section{（1）実験対象地の選定}

PCDRシステムの屋外検証実験対象地を, 大阪大学吹 田キャンパス構内において選定した. 実験対象地につい ては, 実験当時に3次元点群データの取得されている建 物が背景に位置するような, 除去対象物およびカメラ視 点を選定した. 実験対象地を大阪大学吹田キャンパス 21 世紀プラザおよびサイバーメディアセンター周辺とし， 除去対象物をサイバーメディアセンターとした. 図-3に 実験対象地の航空写真を示す. 3次元点群データの取得 されている21世紀プラザおよびレーザーエネルギー学研 究センターが背景に位置するように, サイバーメディア センターを除去対象物とした．また，21世紀プラザの3 次元点群データを用いて位置合わせをおこなうことから， カメラは, 除去対象物であるサイバーメディアセンター

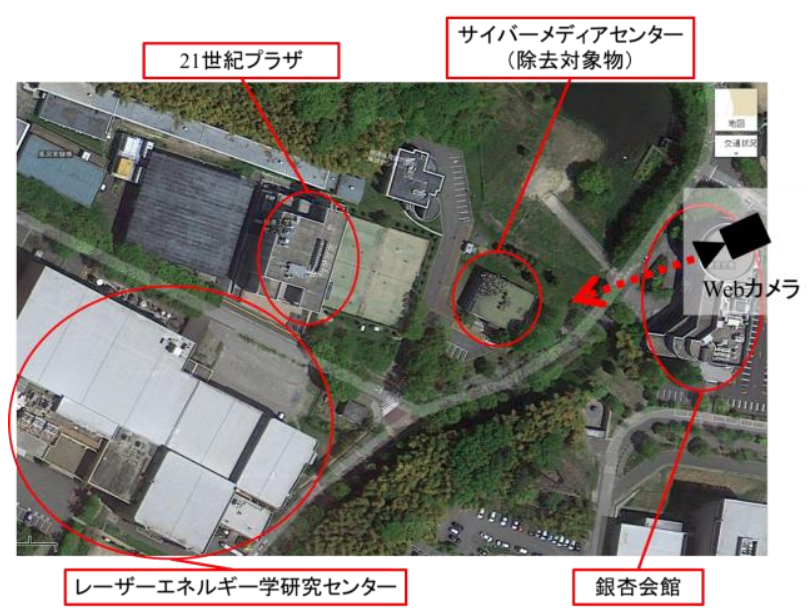

図-3 実験対象地周辺 (Google Mapsより著者が加工)

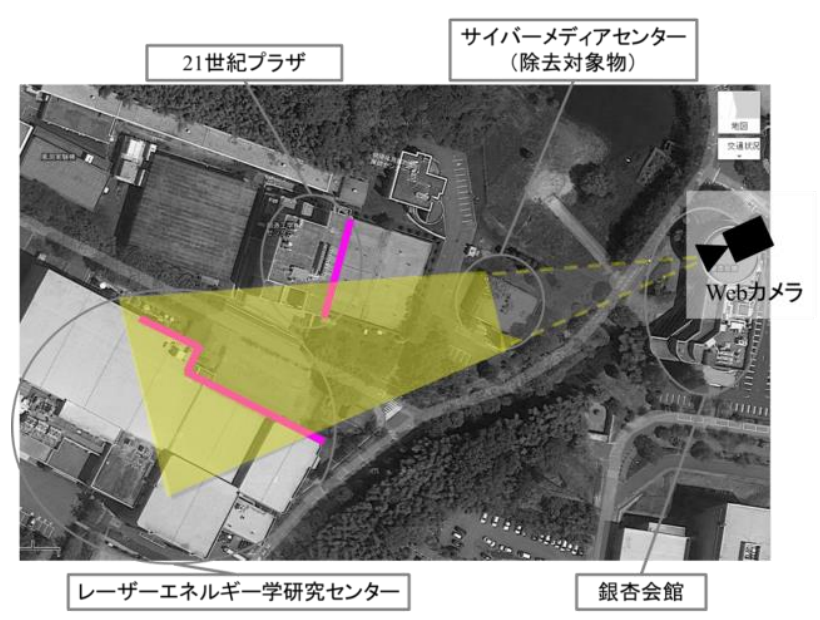

図-4 不可視領域および点群デー夕領域（図の紫の太線は仮 想世界に使用寸る点群デー夕の領域を示寸) 
と21世紀プラザをとらえる必要があるため, カメラの視 点の位置を大阪大学吹田キャンパス銀杏会館の3階とし た. 検証実験時のカメラの視点および方向は, 図-3のカ メラの位置から，赤の点線方向である.

\section{（2）周辺環境の3次元点群データ}

図-4の黄色の領域は，実験時にカメラが除去対象物を とらえる際に，除去対象物の背後にあって見えなくなる 不可視領域である．21世紀プラザとレーザーエネルギー 学研究センターの, 仮想世界として使用する3次元点群 データの領域を, 図-4の紫線で示す. 3次元点群データ は関西工事測量株式会社の3次元レーザースキャナによ って計測された, 大阪大学吹田キャンパス内部の3次元 点群データを使用した. 使用点数は約 350 万点, データ サイズは約180MBである。 また，地面部分の3次元点群 データは取得していなかったため, Google SketchUp 2014 を用いた3次元モデリングによって仮想世界の補正を行 った. 地面の3次元モデルを図-5に示寸. 地面の3次元モ デルのデータサイズは, 370KBである.

\section{(3) DRシミュレーション結果および考察}

カメラの視点から除去対象物をとらえたときの画像を図 -6に示す．仮想世界として使用した 21 世紀プラザおよび レーザーエネルギー学研究センターの点群データの一部 を，図-7に示寸．位置合わせには，21世紀プラザの点群 データのみを使用し，21世紀プラザの壁面における，お およそ同一平面上にあると考えられる6つの特徽点を対 応付けた. 図-8, 図-9の赤点がカメラ画像, 点群データ それぞれの対応付けられた点である. 位置合わせ後, カ メラ画像中の除去対象物に除去対象物の緑色の3次元モ デルが重畳された画像を図-10に示す。二值化処理を行 うための図-10の緑チャネルのグレースケール画像を図11に示寸.二值化処理後のマスク画像を図-12に示す. マスク画像の白色の領域が除去対象物領域である. 図10において, $\quad(\mathrm{R}, \mathrm{G}, \mathrm{B})=(0,255,0)$ であるピクセル数

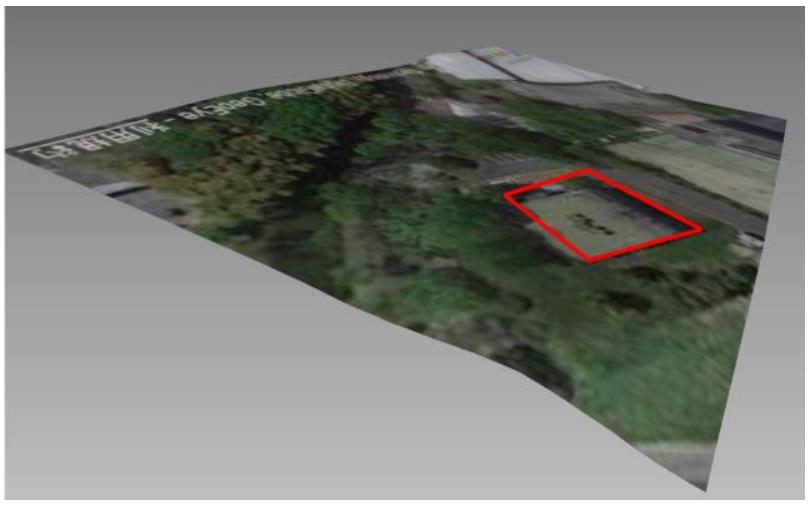

図-5 仮想世界の地面の3次元モデル（赤枠部分はサイバー

$$
\text { メディアセンター) }
$$

は, 29,891ピクセル，図-11において，Value值が255であ るピクセル数は, 29,709ピクセル, 図-12における白色の ピクセル数は，29,706ピクセルであった．このピクセル 数計測結果から, 除去対象物領域を, 概社適切に抽出さ れていると考える. 除去対象物領域に3次元点群データ で構成される仮想世界を重畳した，位置合わせ直後の DRシミュレーション結果を図-13に，位置合わせから約 10秒後のDRシミュレーション結果を図-14に示す．位置 合わせの精度については, カメラ画像中の 21 世紀プラザ の特徵点（図-15の赤点A，B，C，D） と，位置合わせ 後の点群データの同一箇所をピクセル単位のユークリッ

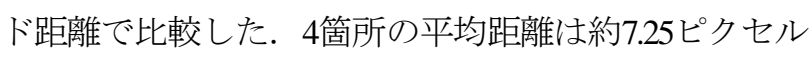
であった．比較に使用した特徵点付近の，1ピクセル当

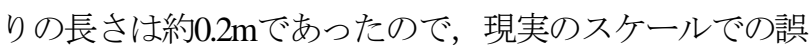
差を計算すると, 約 $1.45 \mathrm{~m}$ の表示誤差となった. PCDRシ ステムは，景観検討を目的としてDRシミュレーション を行うので, 概ね許容範囲の表示誤差であると考える.

PCDRシステムは屋外の大規模構造物を対象としたDRを 実現できることが確認されたが，点群データ計測時の天 候や日照条件によって, 計測した点群データの色みが変 化することも確認された. シミュレーション時の天候に よっては, カメラ画像と3次元点群データから構成され る仮想世界との光学的整合性が取れないといら問題が起 こりうると考えられる. 今後, カメラ画像の現実世界の 色々を仮想世界に反映させ，現実世界と仮想世界の境界 を知覚しないようにする画像処理機能を加えることで, より光学的整合性のとれたDRシミュレーションが可能 となると考えられる.

\section{(4) 対象地を変更しての追加実験}

PCDRシステムの一般性を検証するため, 第3章のPCDR システムの制約条件を考慮した上で, 対象地を変更して 追加実験を行った. 追加実験の対象地は, 大阪大学吹田 キャンパスS4棟および理工学図書館周辺とし，除去対象

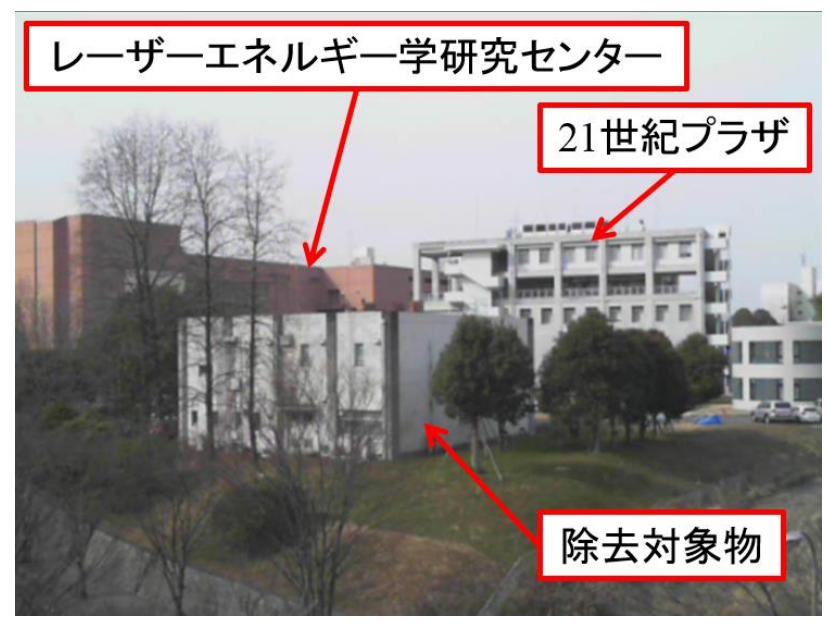

図-6 カメラ画像 


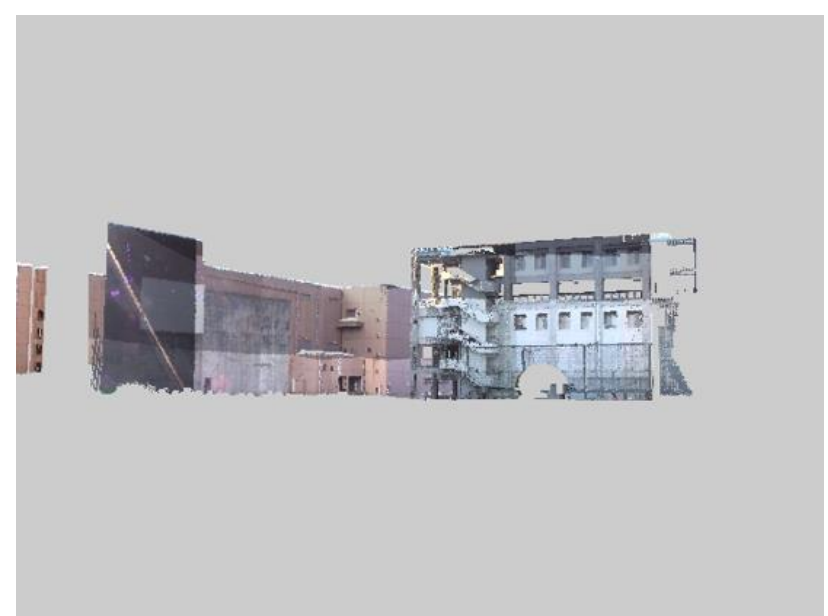

図-7 点群データで構成される仮想世界

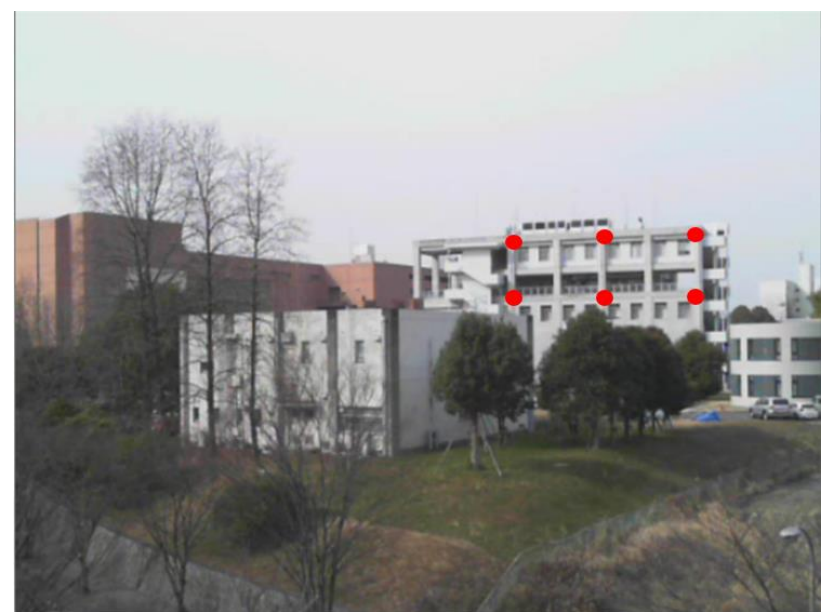

図-8 カメラ画像における位置合わせに用いた対応点（赤点）

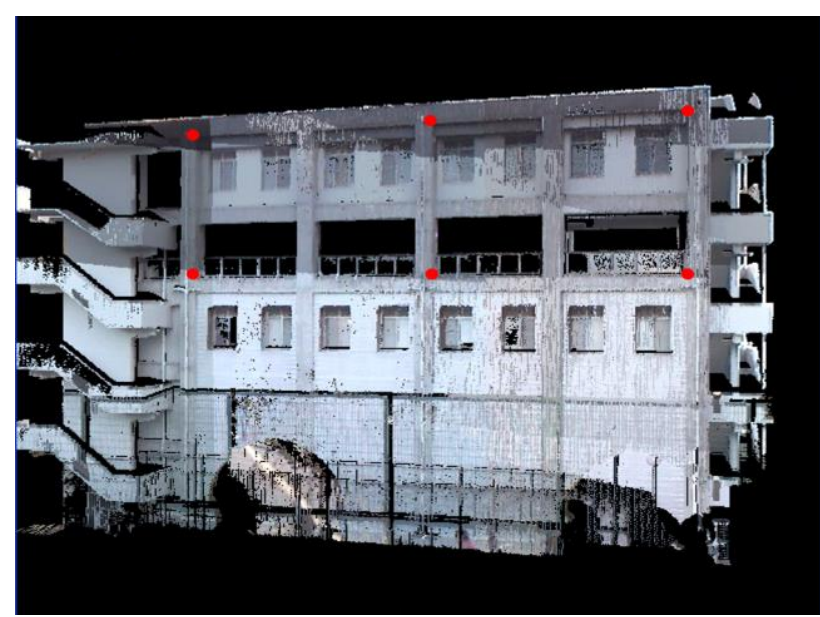

図-9 点群データにおける位置合わせに用いた対応点（赤点）

物をS4棟とした. S4棟は2015年春に解体，撤去され，跡 地が駐車場として利用される予定である．S4棟およびそ の周辺の建物，樹木の3次元点群データは事前に取得し た. 図-16に実験対象地の航空写真を示寸. 3次元点群デ 一タの取得されている理工学図書館、S1棟および周辺の 木々が背景に位置するように，S4棟を除去対象物とした.

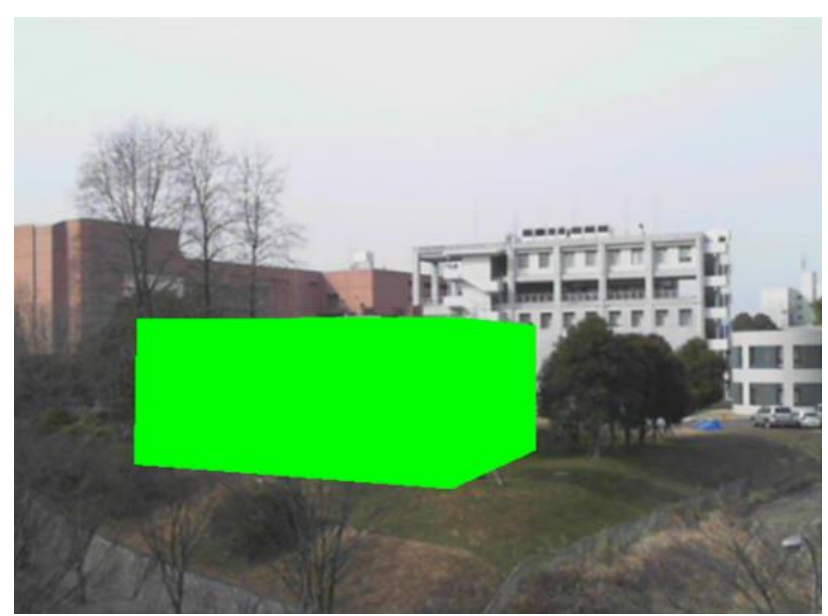

図-10 除去対象物の3次元モデルの重畳

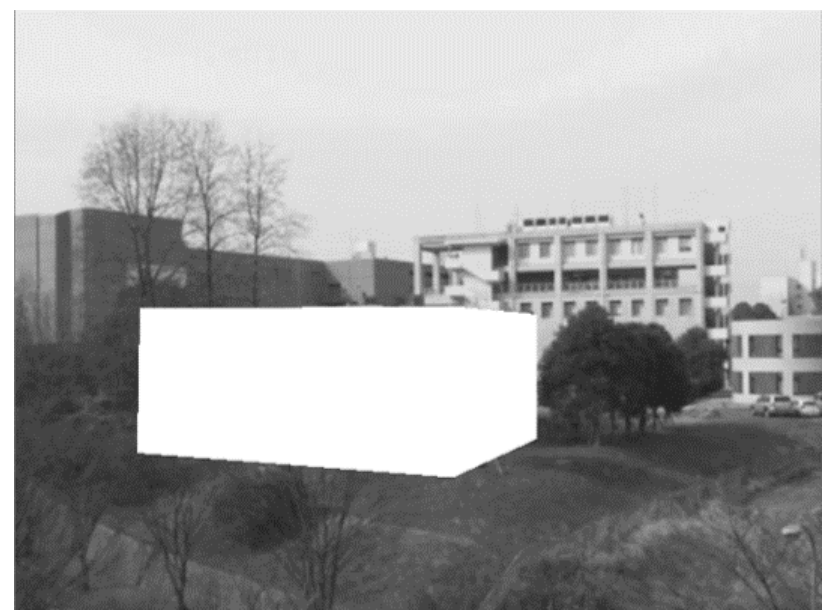

図-11 グレースケール画像

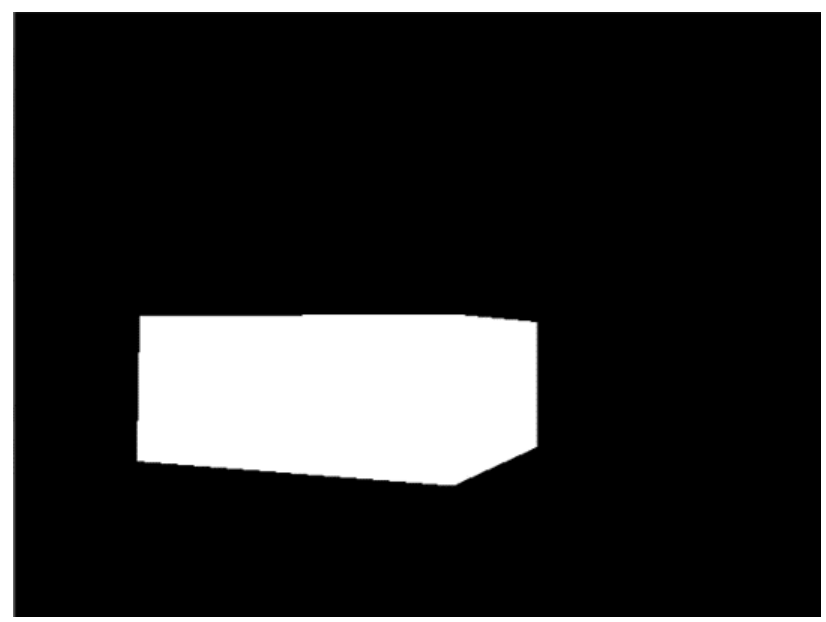

図-12 マスク画像

検証実験時のカメラの視点および方向は, 図-16のカメ ラの位置から, 赤の点線方向である. 図-17の黄色の領 域は，実験時にカメラが除去対象物をとらえる際に，除 去対象物の背後にあって見えなくなる不可視領域である. 理工学図書館, S1棟および周辺の木々の, 仮想世界とし て使用寸る3次元点群データの領域を, 図-17の紫線で示 


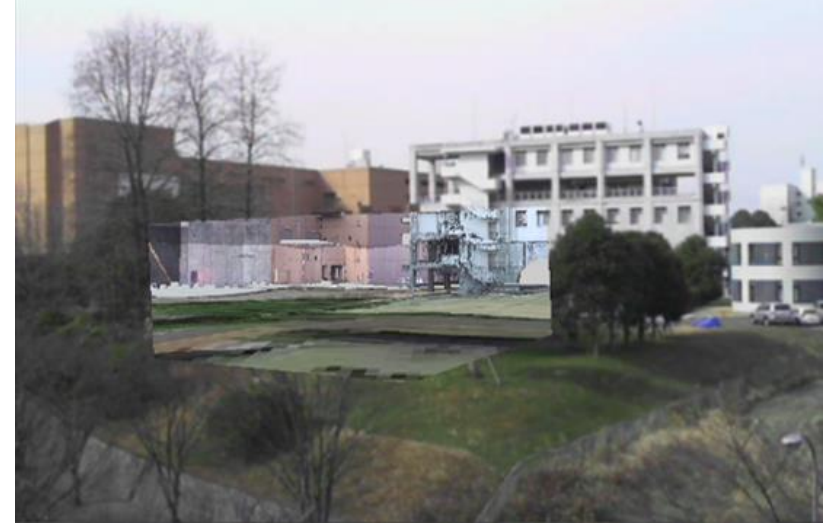

図-13 DRシミュレーション結果（位置合わせ直後）

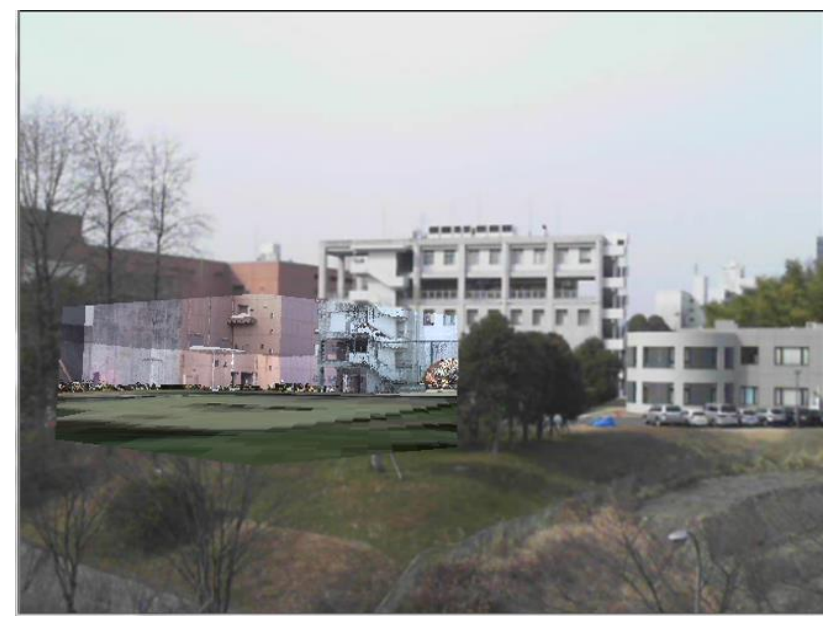

図-14ＤRシミュレーション結果（約10秒後）

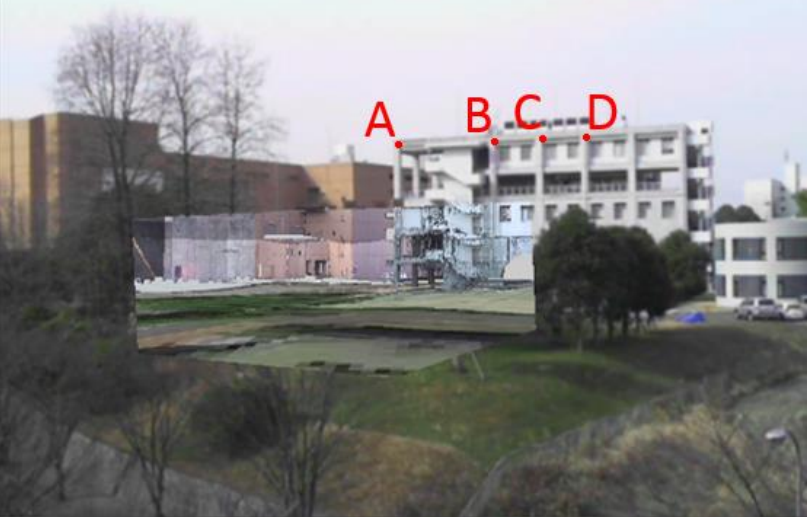

図-15 精度検証に使用した特徵点

す．使用した 3 次元点群データは約 1,500 万点，データサ イズは約750MBである．また，地面部分の3次元点群デ ータは取得していなかったため，Google SketchUp 2014を 用いた3次元モデリングによって仮想世界の補正を行っ た. カメラの視点から除去対象物をとらえたときの画像 を図-18に示す．仮想世界として使用した理工学図書館、

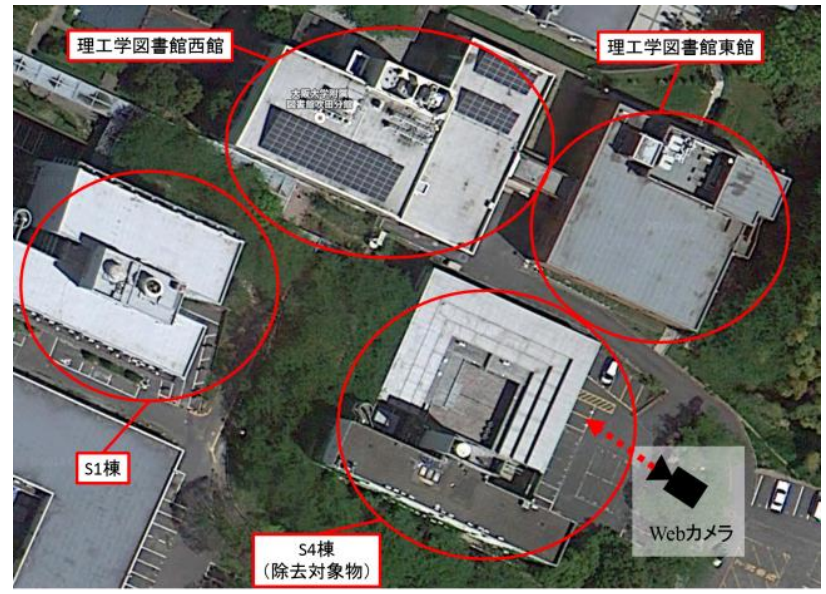

図-16 追加実験対象地周辺（GoogleMapsより著者が加工）

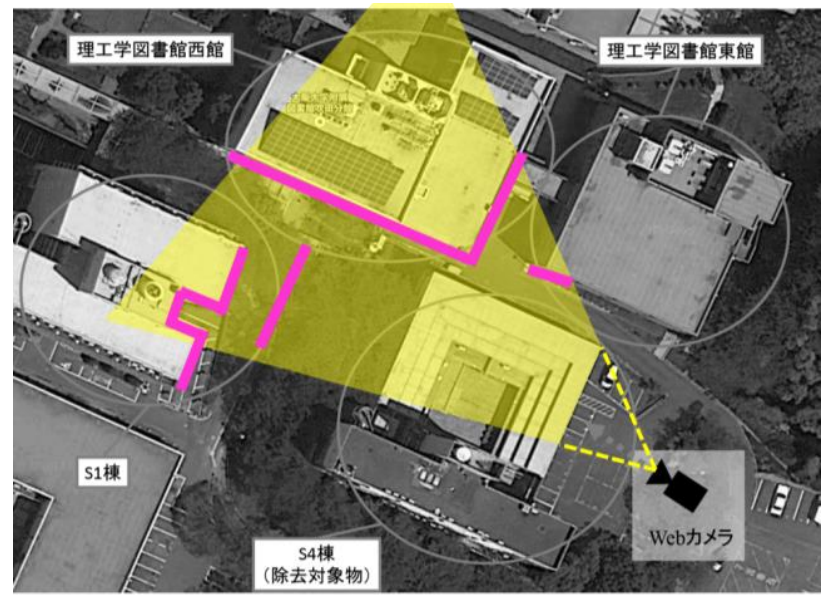

図-17 不可視領域および点群データ領域（図の紫の太線は 仮想世界に使用する点群データの領域を示す)

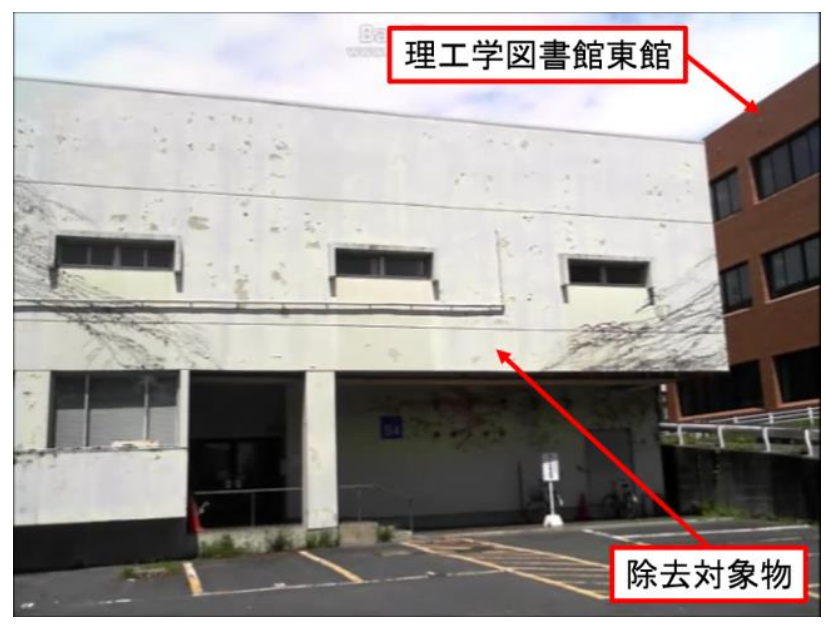

図-18 カメラ画像

S1棟および周辺の木々の，仮想世界として使用する3次 元点群データの一部を, 図-19に示寸. 除去対象物領域 に3次元点群データで構成される仮想世界を重畳した, 位置合わせ直後のDRシミュレーション結果を図-20に, 位置合わせから約10秒後のDRシミュレーション結果を 


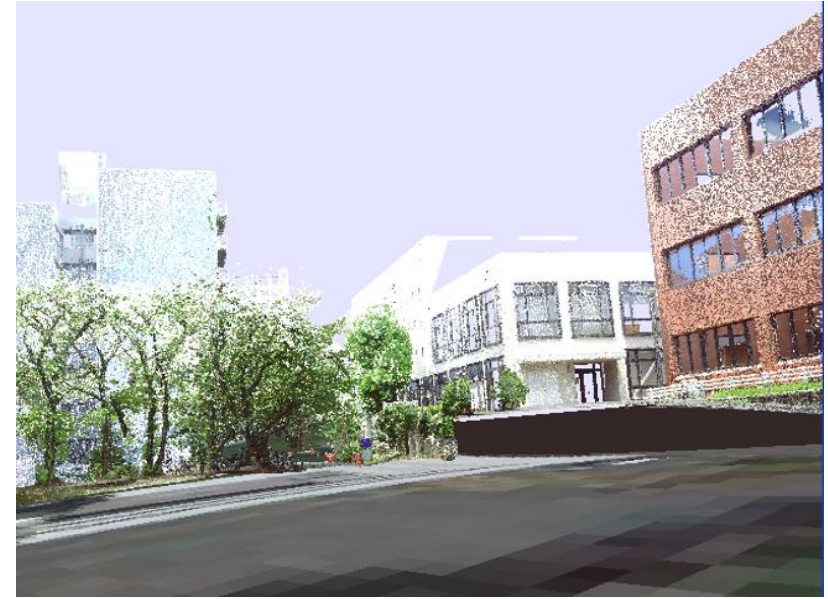

図-19 点群データで構成される仮想世界

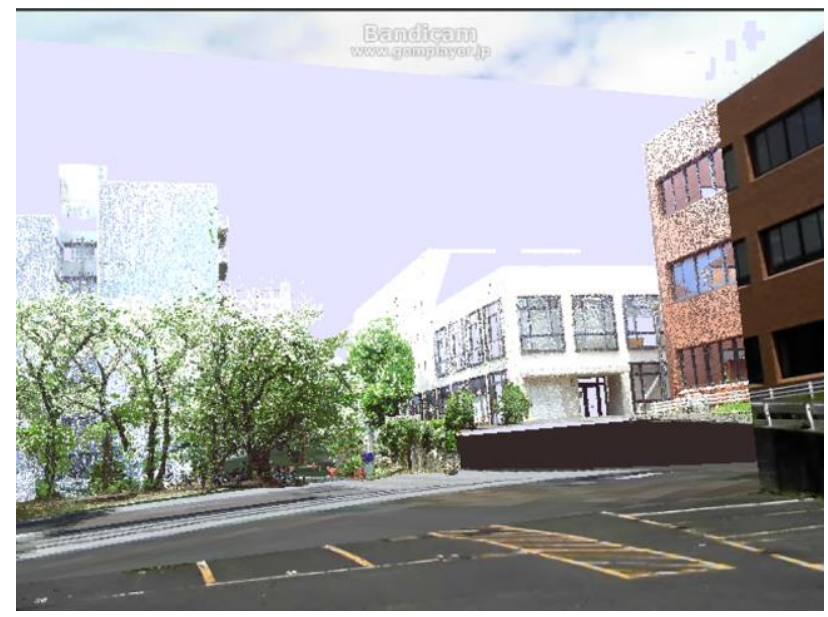

図-20 DRシミュレーション結果（位置合わせ直後）

図-21に示す．(3)と同様の方法で位置合わせ精度の検証 を行ったところ, 平均表示誤差は約 9.0 ピクセルで，比 較に使用した特徵点付近の, 1ピクセル当りの長さは約0. 05mであったので，現実のスケールに換算した表示誤差 は, 約 $0.45 \mathrm{~m}$ であった。精度検証に使用した特徵点を, 図-22の赤点で示す.こちらの対象地においても, 許容 範囲内の表示誤差であったと考える．PCDRシステムは， 他の対象地でもDRシミュレーションを行うことが可能 であることが確認された．樹木の上部など，色情報を計 測できず，白色となってしまう点があることも確認され た.

\section{5. 結論}

本研究では，屋外の大規模構造物を対象としたリアル タイムレンダリング方式のDRシミュレーションシステ ム「PCDRシステム」を開発した。本研究の結論は以下 の通りである.

・本研究で開発したPCDRシステムによるDR手法により,

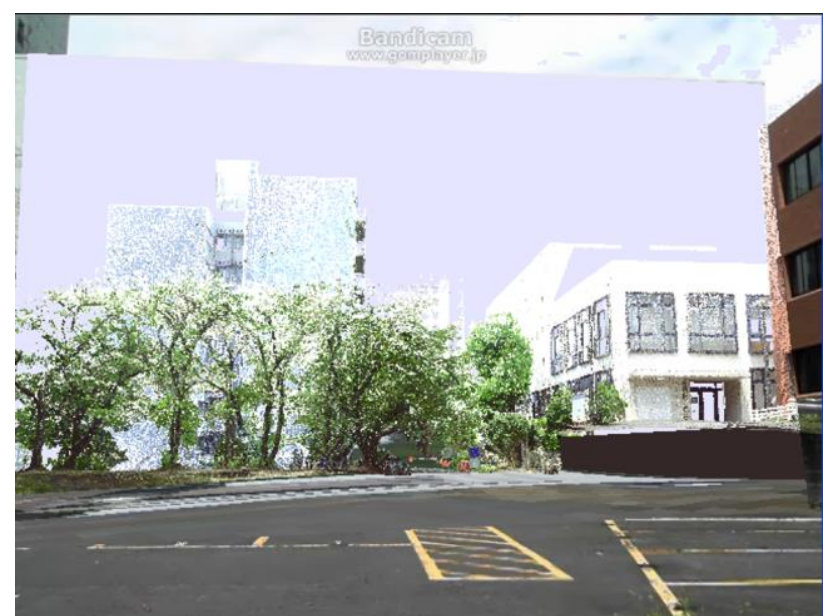

図-21ＤRシミュレーション結果（位置合わせ約10秒後）

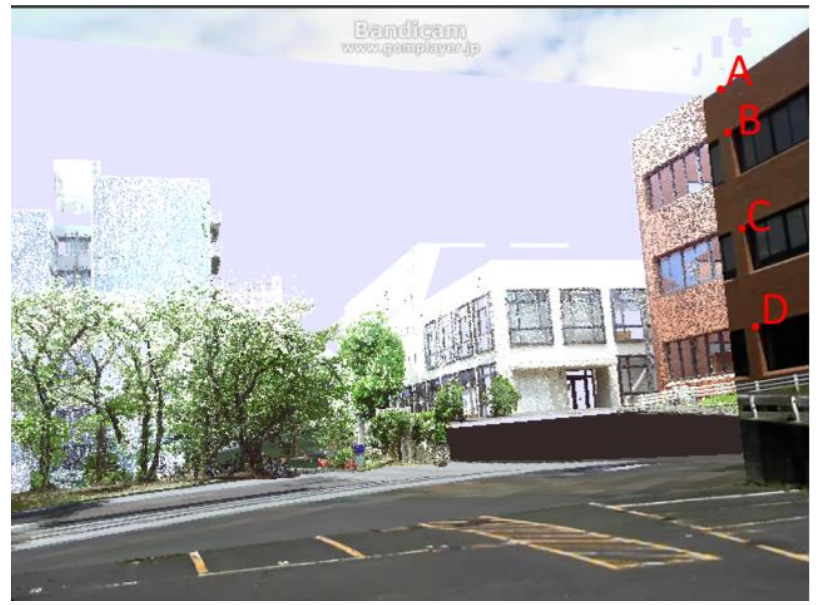

図-22＼cjkstart精度検証に使用した特徵点

現在のAR手法では適切な検討が難しい，屋外の大規 模構造物の解体，撤去を想定した，幾何学的整合性の とれた景観検討が可能であることが確認された.

・PCDRシステムによるDR手法は，建物の解体，撤去後 の新設構造物のARシミュレーションに適用可能であ る事が確認された.

今後は，仮想世界と現実世界の色調が異なる問題を解 決していきたい.

謝辞 : 本研究を進めるにあたり，関西工事測量株式会社 から多大なるご協力を頂きました。ここに謝意を表しま す.

\section{参考文献}

1）国土交通省：国土交通省所管公共事業における景観 検討の基本方針，

http://www.mlit.go.jp/kisha/kisha07/13/130330/01.pdf ， (2013.2.6 参照)

2) 物部寛太郎, 田中成典, 伊藤裕二, 武井千雅子, 許 会慶 : 3 次元 VR システムを用いた住民参加型景観シ ミュレーションツールの研究開発, 情報処理学会, 
全国大会講演論文集 第 70 回平成 20 年(3), ”3-117”““3118 ", 2008.

3) 矢吹信喜 : VR, MR, AR の基礎と建設分野への適用 について, 日本建設情報総合センター, JACIC 情報 103 号, Vol.26, No.3, pp.6-16, 2011.

4) Paul Milgram, Haruo Takemura, Akira Utsumi, Fumio Kishino : Augmented reality : a class of displays on the reality-virtuality continuum, The International Society for Optical Engineering Vol. 2351, Telemanipulator and Telepresence Technologies, 1994.

5) V. Lepetit and M. -O. Berger : A Semi-Interactive and Intuitive Tool For Outlining Objects in Video Sequences With Application To Augmented and Diminished Reality, Proceesings of the International Symposium on Mixed Reality, 2001.

6) F. I. Cosco, C. Garre, F. Bruno, M. Muzzupappa and M. A. Otabuy : Augmented touch without visual obtrusion, Proc. International Symposium on Mixed and Augmented Reality (ISMAR 2009), pp.99-102, 2009.

7) 榎本暁人, 斎藤英雄 : 複数のハンディカメラを利用 した Diminished Reality, MIRU 2007, pp.1277-1282, 2007.

8）森尚平, 一刈良介, 柴田史久, 木村朝子, 田村秀 行：隠消現実感の技術的枠組と諸問題〜現実世界に 実在する物体を視覚的に隠蔽・消去・透視する技術 について〜，日本バーチャルリアリティ学会論文誌 Vol.16, No.2, pp239-250, 2011.

9) 瀧口純一 : 高精度 GPS 移動計測装置三菱モービルマ ッピングシステム，情報処理学会研究報告. CVIM, [コンピュータビジョンとイメージメディア], 2011CVIM-176(20), pp.1-5, 2011.

10) Mark Fiala : The SQUASH 1000 Tangible User Interface System, Proceedings of the Third IEEE and ACM International Symposium on Mixed and Augmented Reality (ISMAR 2005)
11）神原誠之, 横矢直和, 竹村治雄 : マーカと自然特徵 点を併用した広範囲見回し可能なステレオビデオシ 一スルー拡張現実, 電子情報通信学会技術報告. PRMU, パターン認識・メディア理解 101 号, pp4753, 2002.

12) 佐藤智和, 横矢直和 : AR/MR における幾何位置合わ せ手法の現状-自然特徵を使った手法の研究動向と課 題, 第 14 回日本バーチャルリアリティ学会大会論文 集, 2009.

13) N. Yabuki, Y. Hamada and T. Fukuda : Development of an Accurate Registration Technique for Outdoor Augmented Reality Using Point Cloud Data, Proceedings of 14th International Conference on Computing in Civil and Engineering, Moscow, 2012.

14) 高奥信豪, 矢吹信喜, 福田知弘: 3 次元レーザースキ ヤナの点群データを用いた屋外拡張現実感技術の検 討, 平成 23 年度日本建築学会近畿支部研究報告書, 第 51 号・計画系, pp.441-444, 2011.

15）鈴木宏正，神鳥泰章，金井崇，木村文彦：測定点群 からの三角形メッシュ生成（第 1 報）一空領域削除 法と陰関数再構成法による初期メッシュ生成一，精 密工学会誌, 第 64 巻, 第 9 号, pp.1314-1319, 1998.

16) 鈴木宏正, 神鳥泰章, 金井崇, 木村文彦 : 測定点群 からの三角形メッシュ生成（第 2 報）一初期メッシ ユの改良法一, 精密工学会誌, 第 64 巻, 10 号, pp.1461-1466, 1998.

17) 北川憲佑, 矢吹信喜, 福田知弘 : 都市模型から 3 次 元計測された点群の最適化システムに関する研究 : GUI とテクスチャ生成機能の開発（都市計画），平 成 23 年度日本建築学会近畿支部研究報告書, 第 51 号・計画系, pp.569-572, 2011.

(2014.10.16 受付)

\title{
DIMINISHED REALITY FOR AR SIMULATION OF DEMOLITION AND REMOVAL OF URBAN OBJECTS
}

\author{
Nobuyoshi YABUKI, Takashi TANEMURA, Tomohiro FUKUDA and Takashi \\ MICHIKAWA
}

Augmented Reality (AR) which extends an environment with virtual objects has been studied extensively and has gained popularity in landscape assessment. However, existing AR approaches cannot correctly simulate views after the demolition and removal of outdoor buildings. To resolve this problem, Diminished Reality (DR) has been paid attention. DR is a technique which can remove the image of an existing object and paste the background image on the area of the diminished object in real time. It is well known that accurate registration of video camera's position and direction is quite difficult in AR or DR if it is used outdoors. On the other hand, a measurement technology of point cloud data by using 3D laser scanner has also been focused. Point cloud data can be measured in a wide-range scale such as a city or a country by using Mobile Mapping System (MMS) which is a laser scanner on a moving vehicle. Considering rapid progress of information technology in recent years, it is expected that we can get point cloud data of any place freely in near future. The registration methods using point cloud data for AR have been studied. Therefore, in this research, a Diminished Reality simulation system using point cloud data was proposed. This system facilitates landscape simulation and assessment of demolition and removal of outdoor buildings beforehand. 